\title{
The Sterilization Effect of Methylene Blue, Formalin, and Iodine on Egg and Adult Stage of Marine Medaka, Oryzias dancena
}

\author{
In-Seok Park*, Se-Won Baek*, and †Ki Hwan Moon \\ Division of Marine Bioscience, College of Ocean Science and Technology, \\ Korea Maritime \& Ocean University, Busan 49112, Korea
}

\begin{abstract}
The sterilization effects of methylene blue (MB), formalin, and iodine on the egg of marine medaka, Oryzias dancena, were investigated for disinfecting naididae worm, Chaetogaster diastrophus through sterilization. To determine harmfulness of $\mathrm{MB}$, formalin, and iodine, lethal concentrations $50\left(\mathrm{LC}_{50}\right)$ of three chemicals were analyzed in the eggs of marine medaka. The sterilized periods of each chemical were set at $1 \mathrm{hr}$. Sterilized rates of naididae worm in each chemical were significantly affected and increased drastically as the concentration of each chemical increased $(p<0.05)$. Sterilization abilities of naididae worm were most effective for formalin, but survival rates of egg and hatched rates for formalin were lowest among each chemical. The $\mathrm{LC}_{50}$ of MB over 96 hrs were 185.26, 103.84, and 127.15 ppm for adults, juveniles, and eggs respectively. The toxic effects of MB were clearly dose dependent for each life stage $(p<0.05)$. The toxicity sensitivity of juveniles to MB was dramatically higher than that of other groups. In $48 \mathrm{hrs}$ after sterilization, cortisol and glucose concentrations of the adult group with MB treatment were significantly higher than those of the adult group with no treatment $(p<0.05)$. This research provides useful data on sterilization effect of $\mathrm{MB}$, formalin, and iodine, acute toxicity in marine medaka egg and toxicity, sensitivity of life stage of MB in marine medaka.
\end{abstract}

Key words : Acute toxicity, Formalin, Iodine, Methylene blue, Oryzias dancena, Sterilization

\section{INTRODUCTION}

We adopted the experimental marine medaka, Oryzias dancena because the marine medaka is gaining attention as an experimental animal in the aquaculture. This fish is a truly euryhaline teleost with a great capacity for hypo- and hyper-osmoregulation (Roberts, 1998; Im et al., 2016). It also has a short interval between generations with spawning possibilities just 60 days after hatching (Song et al., 2009; Park et al., 2011, 2016, 2017, 2018). The physiological adjustment abilities of marine medaka are adaptable across a wide spectrum of salinities, ranging from complete freshwater to normal seawater (Inoue \& Takei, 2003; Kang et al., 2008; Cho et al., 2011; Park et al., 2016, 2017). Much attention has been directed toward extending the utility of functional transgenic marine medaka strains for ornamental purposes because they can survive at any spontaneously occurring salinities (Cho et al., 2011; Park et al., 2018).

The marine medaka inhabits brackish water or freshwater around Bengal bay and Malay peninsula, and this species is not indigenous to Korea (Kang et al., 2008; Park et al.,

\footnotetext{
Manuscript received June 13, 2019, Accepted August 27, 2019

$\dagger$ Corresponding Author : Ki Hwan Moon, Division of Marine Bioscience, College of Ocean Science and Technology, Korea Maritime \& Ocean University, Busan 49112, Korea. Tel: +82-51-410-4754, Fax: +82-51-404-4750, E-mail: khmoon@kmou.ac.kr

* These authors contributed equally to this work.
}

This is an Open Access article distributed under the terms of the Creative Commons Attribution Non-Commercial License (http:// creative-commons.org/licenses/by-nc/3.0) which permits unrestricted non-commercial use, distribution, and reproduction in any medium, provided the original work is properly cited. 
2011, 2016, 2017; Im et al., 2016). So, this species has been transported mainly from Southeast Asia to Korea on a large scale, by using the method of quarantine transportation. However, marine medaka is free of quarantine transportation, resulting imported fish might be infected by parasite, fungi or worms, and they sometimes die of parasitic infection soon after arrival or during transportation. Kim et al. (2002) found several species of parasites in ornamental fish imported to Australia, and emphasized the importance of quarantine practices to prevent the accidental introduction of exotic pests. This is because such pests are likely to cause economic losses, in particular in case of those pathogens becoming established among native fish species (Kim et al., 2002). Formalin was used as a bactericide in the aquaculture industry, and methylene blue (MB) and iodine are also widely used as an effective bactericide along with formalin, potassium permanganate, and sodium chloride (Park et al., 2002).

MB (3,7-Bis (dimethylamino) phenothiazin-5-ism chloride) (Fig. 1) assumes a shape of odorless dark green crystals or crystalline powder with a bronze luster (Patel, 2006). It is one of a group of thiazinium halides, or phenothiazin-5ium chloride compounds, which have a wide variety of uses, including biomedical and biological activity applications (Moura \& Cordeiro, 2003). A search of PubMed by the term MB identified over 10,000 abstracts dating back to 1914, highlighting its role in biomedical science over many years (Auerbach et al., 2010). Currently, MB is used in human and veterinary medicine in a number of therapeutic and diagnostic procedures including a bacteriological

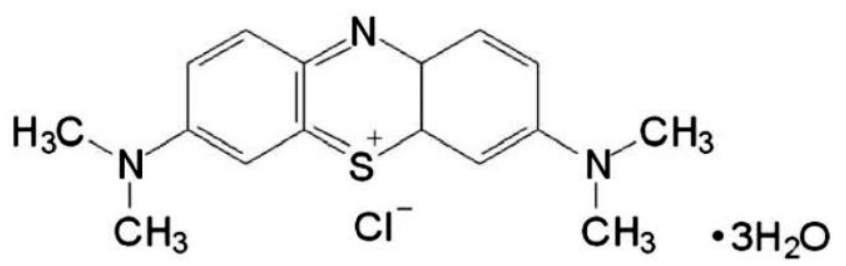

Fig. 1. The chemical structure of methylene blue trihydrate. stain, a redox coloring agent, a targeting agent for melanoma, an anti-methemoglobinemic, an antiseptic in the livestock and aquaculture industries, a disinfectant for curing ichthyophthiriasis, a treatment for ifosfamide-induced encephalopathy, a treatment of vasoplegia associated with septic shock, and as a tracer in parathyroid surgery (Patel, 2006).

Acute toxicity researches are used to determine the sensitivity of experimental animals to various toxic chemicals (De Listle \& Roberts, 1988). The toxicity effect of toxic chemicals on fish has been described at several levels of biological organization, mostly in animals exposed to waterborne chemicals. Effects include changes in biochemistry, anatomy, and physiology. For example, at the cellular level, waterborne copper inhibits Na K-ATPase causes lipid peroxidation and can produce morphological damage that is associated with natrium balance disturbances in gill tissue and with altered energy metabolism in the liver (Segner, 1987; Sola et al., 1995; Handy et al., 1999). These biochemical and structural changes caused by toxic chemicals underlie major hematological disturbances, which ultimately affect respiratory and renal restoration (Handy et al., 1999). Biochemical and structural changes involving tissue lesions of the gills include desquamation, necrosis, hypertrophy, fungosity of the gill epithelium, fusion of the lamella, and changes in salt cells; tissue lesions on the liver involve the vacuolization and swelling of interstitial cells and alcian blue positive reactions of the bile duct epithelium; tissue lesions on the kidneys produce hypertrophy of the tubular epithelial cells, vacuole body formation and necrosis inside tubules, the disappearance of tubules and the glomerulus, and the advent of gluttonizing cell populations (Kim et al., 2003).

So far, no study has been performed for the acute toxicity effects of MB on marine medaka. The objective of our study was: (i) to assess the sterilization effect of each chemical on the egg of marine medaka; (ii) to determine optimum concentration of each chemical and less harmful 
chemical by comparing the hatching rate, the sterilization rate, and the lethal concentration $50\left(\mathrm{LC}_{50}\right)$ values at the age of egg of the marine medaka; (iii) to assess the acute toxicity of less harmful chemical on the experimental fish, marine medaka for curing disease through sterilization; (iv) to determine which life stage of marine medaka is most sensitive to the exposure to less harmful chemical by comparing $\mathrm{LC}_{50}$ values; (v) to investigate stress response of $\mathrm{MB}$ in adult marine medaka through the analysis of plasma cortisol and glucose.

\section{MATERIALS AND METHODS}

\section{Experimental fish and egg}

Experimental group of marine medaka, Oryzias dancena in this study were reared by the method of Park et al. (2011). For collecting eggs, the fish whose body length were over $25 \mathrm{~mm}$ were used in this experiment and 35 males and 15 females of marine medaka were placed in each of two aquariums, and 2,000 fertilized eggs were collected immediately by net. The fertilized eggs of experimental group $(n=100)$ were reared in $100 \mathrm{~L}$ glass aquarium.

The experiment was conducted from 29 April to 31 May 2019. We randomly selected 900 eggs. Based on the results of Song et al. (2009), eggs in the early blastula stage $(n=300)$ were chosen; this stage was observed $8 \mathrm{hrs}$ after fertilization (Song et al., 2009). Using a biological microscope (Axioskop, Zeiss, Germany), a number of eggs and a number of naididae worms, Chaetogaster diastrophus that is parasitie on the outside egg membrane of marine medaka were synchronized for using in this experiment (Fig. 2). Selected eggs were fertilized on the same day to acquire eggs at the same stage of development.

2. Sterilization effect of methylene blue, formalin, and iodine

Three hundred eggs of each chemical treatment and each exposure dose were quarantined and habituated in a
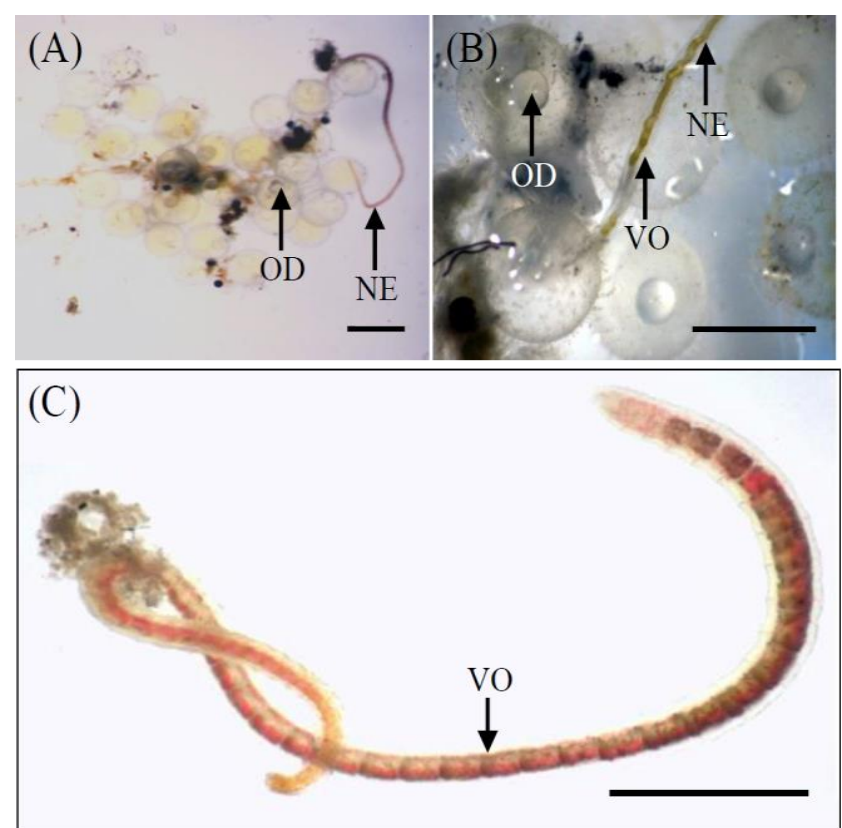

Fig. 2. External morphology of naididae worm, Chaetogaster diastrophus and egg of marine medaka, Oryzias dancena. (A) and (B) naididae worm inhabiting on egg of marine medaka; (C) naididae worm. Scale bars are $100 \mu \mathrm{m}$. NE, naididae worm; OD, oil droplet; VO, viscus organ of worm.

20-L glass aquarium. The rearing water was a mixture of dechlorinated fresh water and seawater with a total salinity of $1.0 \pm 0.3$ ppt. The values of the ammonia, nitric acid, conductivity, and $\mathrm{pH}$ of the immersion group during the experimental period were $0.02 \mathrm{ppm}, 2.4 \pm 0.1 \mathrm{ppm}, 0.01$ ppm, $238 \mu \mathrm{s} / \mathrm{cm}$, and 7.2-7.4 respectively. The oxygen concentration was adjusted to $8.2 \pm 0.3 \mathrm{mg} / \mathrm{L}$ using the air pump. Water temperature was controlled automatically and maintained at $26 \pm 0.5^{\circ} \mathrm{C}$ during the experimental period.

The experimental concentration of MB, formalin, and iodine was set by a preliminary experiment (formalin: Merck, Germany; iodine: Sigma, USA; MB: Sigma, USA). The concentration of MB was identified at three concentrations of 40,80 , and $160 \mathrm{ppm}$. The concentration of formalin for eggs was set at $10 \%, 20 \%$, and $30 \%$. The concentration of iodine for eggs was set at $10 \%, 30 \%$, and $60 \%$. The experimental period was set at $1 \mathrm{hr}$, and experiments were executed in triplicate. 


\section{Acute toxicity}

The acute toxicity experiment was conducted from 2 June to 30 June 2019. We randomly selected 300 specimens from adults, juveniles, and eggs of marine medaka respectively. The adults and juveniles used in the experiment were weighed using an electronic balance (Shimadzu, Type AX200, Japan) and measured using vernier calipers (Mitutoyo, CD-20CP, Japan).

Twenty specimens of each stage by fish and each exposure dose were quarantined and habituated in a $20-\mathrm{L}$ glass aquarium for 3 days. The rearing water was a mixture of dechlorinated fresh water and seawater with a total salinity of $.2 .8 \pm 0.3$ ppt. The values of the ammonia, nitric acid, conductivity, and $\mathrm{pH}$ of the MB-immersion group during the experimental period were $0.02 \mathrm{ppm}, 2.4 \pm 0.1$ ppm, $0.01 \mathrm{ppm}, 238 \mu \mathrm{s} / \mathrm{cm}$, and 7.2-7.4 respectively. Thirty percent of the total volume of the rearing water in the aquarium was exchanged every day. The oxygen concentration was adjusted to $8.2 \pm 0.3 \mathrm{mg} / \mathrm{L}$ using the air pump. Water temperature was controlled automatically and maintained at $26 \pm 0.5^{\circ} \mathrm{C}$ during the experimental period. The photoperiod was set to $13 \mathrm{hrs}$ light, $11 \mathrm{hrs}$ dark.

The final concentration of $\mathrm{MB}$ was arranged during the preliminary experiment. The acute toxicity of MB on adult marine medaka was investigated at five concentrations, $120,150,180,210$, and $240 \mathrm{ppm}$. The concentration of MB for juveniles and eggs was set at 40, 80, 120, 160, and 200 ppm. Experimental water was used as rearing water, and MB-saturated solution was added to the experimental water by the standard of the experimental concentration of MB. Control groups were also established. The experimental period was set at $96 \mathrm{hrs}$, and experiments were executed in triplicate. All groups were fasted for $24 \mathrm{hrs}$ before the experiment. During the experiments, experimental water and MB solutions were exchanged every day to prevent contamination.

\section{Histological analysis}

Dead adult individuals in the 240-ppm-MB group were removed from the aquarium immediately every day. The fresh gills and livers of these specimens were fixed in $10 \%$ neutral formalin solution ( $100 \mathrm{~mL}$ formalin, $6.5 \mathrm{~g} \mathrm{Na}_{2} \mathrm{HPO}_{4}$. $12 \mathrm{H}_{2} \mathrm{O}, 4.5 \mathrm{~g} \mathrm{KH}_{2} \mathrm{PO}_{4}, 900 \mathrm{~mL}$ DW) for 5 days. The kidneys could not be removed from fresh specimens, so the whole body was fixed in $10 \%$ neutral formalin solution for 5 days. All samples were then refixed in Boun's solution for $24 \mathrm{hrs}$. Samples were prepared in $6 \mu$ m-thick paraffin sections, placed on slides, stained with haematoxylin and eosin-phroxine $\mathrm{B}$, and observed under a microscope (Axioskop, Zeiss, Germany). Control group individuals were also examined, and the photographs of tissues of control group and MB-immersion groups were taken.

\section{Whole-body cortisol and glucose response to methylene blue treatment}

We conducted this experiment to observe the effect of stress on the whole-body cortisol and glucose levels of fish under exposure of MB. While $48 \mathrm{hrs,} \mathrm{samples} \mathrm{of} \mathrm{MB}$ immersion group were exposed at $100 \mathrm{ppm}$ of MB. Control samples were not under MB treatment, but their cortisol levels were measured. For these measurements, 20 fish were used in each experimental group, and no distinction was made between male and female fish. We measured the whole-body cortisol and glucose levels of the control fish before the experiment. Individual fish were blotted onto paper towels to remove excess water, immediately frozen in liquid nitrogen for $10-30 \mathrm{sec}$ and placed in individual $5.0-\mathrm{mL}$ plastic screwcap centrifuge tubes. The samples were stored at $-80^{\circ} \mathrm{C}$ until we extracted the cortisol.

The term "whole-body cortisol" is used to describe the portion of corticosteroid extracted and measured with a cortisol-specific radioimmunoassay (RIA). The whole, frozen marine medaka individuals were thawed, weighed individually, and placed in a glass test tube $(15 \times 85 \mathrm{~mm})$. Each fish was homogenized in deionized water $(0.5 \mathrm{~mL})$ for 45 75 sec using a Tissue-Tearor Homogenizer (model 985370- 
04; BioSpec Products, Inc., Bartlesville, OK, USA). The homogenate on the Tissue Tearor J probe was rinsed into the sample tube with an additional $0.5 \mathrm{~mL}$ of deionized water.

The homogenized samples were vortexed briefly and placed on ice. The probe was cleaned with each samples in distilled water, followed by absolute ethanol, and was then rinsed again with distilled water. The homogenized contents of the glass test tube were transferred to a larger test tube $(16 \times 125 \mathrm{~mm})$ to facilitate extraction. The original tube was rinsed with diethyl ether (0848-10; Mallinckrodt Baker, Inc., Paris, KY, USA), which was transferred to a larger tube for subsequent extraction. Each sample was extracted twice with $8 \mathrm{~mL}$ of diethyl ether. For each extraction, the tube was vigorously vortexed with ether for $30 \mathrm{sec}$ and briefly centrifuged $(400 \times \mathrm{g}$ for $2-3 \mathrm{~min}$ ) to separate the aqueous and ether layers. The bottom layer (aqueous homogenate) was frozen in liquid nitrogen for 20 sec and the top ether layer was poured into a new test tube $(16 \times 100 \mathrm{~mm})$ and dried in a Speed-Vac centrifuge (SVC100H; Savant Instruments, Inc., Holbrook, NY, USA). The extraction efficiency was achieved for each extraction by adding tritiated cortisol (hydrocortisone, $\left[1,2,6,7-{ }^{3} \mathrm{H}\right]-$ cortisol; \#NET-396; Dupont NEN Research Products, Boston, MA, USA) to the homogenized samples $(n=20)$ and extracting the samples with the method described above. All sample cortisol levels were corrected for extraction efficiency.

After the second extraction, the samples were dried in a fume hood overnight, reconstituted with $1 \mathrm{~mL}$ of phosphatebuffered saline containing 1\% gelatin (Sigma, St. Louis, MO, USA), vortexed for $30 \mathrm{sec}$, and stored at $4{ }^{\circ} \mathrm{C}$. The whole-body glucose level was analyzed according to the methodology of Raabo \& Terkildsen (1960), with Kit 510 (Sigma, USA), in which the production of $\mathrm{H}_{2} \mathrm{O}_{2}$ by glucose oxidase in the presence of $o$-dianisidine was evaluated as the increase in absorbance at $450 \mathrm{~nm}$. The experiment was performed twice, and the results are reported as the means $\pm \operatorname{SD}(n=20)$, unless otherwise stated.

\section{Statistical analysis}

The $\mathrm{LC}_{50}$ of each chemical regarding treatment times and the $96-\mathrm{hr} \mathrm{LC}_{50}$ of MB on each life stage were analyzed by probit analysis $(p<0.05)$ using the SPSS statistical package (SPSS, Inc., SPSS 9.0, Chicago, IL, USA). Significant differences between groups were analyzed by ANOVA $(p<0.05)$ using the SPSS statistical package (Kang et al., 2008).

\section{RESULTS}

The sterilized rate, survival rate, hatching rate, and abnormal rate of marine medaka, Oryzias dancena for each chemical group were recorded in Table 1. The sterilized rate of naididae worm, Chaetogaster diastrophus in each chemical was significantly affected and increased drastically as the concentration increased $(p<0.05)$. The survival rate of marine medaka embryos in each chemical was significantly affected and decreased drastically as the concentration increased $(p<0.05)$. The hatching rate in each chemical was significantly affected and decreased drastically as the concentration increased $(p<0.05)$. The abnormal rate in each chemical was significantly affected and increased drastically as the concentration increased $(p<0.05)$. The sterilization ability of formalin was most effective, but the survival rate and hatching rate of eggs were lowest among all chemicals. MB and iodine were safer than formalin, but the sterilization ability of MB and iodine were lower than formalin.

Fig. 3 shows the $\mathrm{LC}_{50}$ associated with treatment times of each chemical to marine medaka eggs. At $1 \mathrm{hr}$, the $\mathrm{LC}_{50}$ of. $\mathrm{MB}$, formalin, and iodine was $1,547.1 \mathrm{ppm}, 22.6 \%$, and $82.4 \%$ respectively. The $\mathrm{LC}_{50}$ of each chemical at $4 \mathrm{hrs}$ was $1,207.4 \mathrm{ppm}, 14.8 \%$, and $70.1 \%$ respectively, and that at $12 \mathrm{hrs}$ was $801.5 \mathrm{ppm}, 10.5 \%$, and $41.2 \%$ respectively. The $\mathrm{LC}_{50}$ of each chemical at $24 \mathrm{hrs}$ was $504.4 \mathrm{ppm}, 8.8 \%$, and $28.7 \%$ respectively, and that at $48 \mathrm{hrs}$ was $200 \mathrm{ppm}$, 
Table 1. Effects of each chemicalon naididae worm, Chaetogaster diastrophus and the eggs of marine medaka, Oryzias dancena

\begin{tabular}{|c|c|c|c|c|c|c|}
\hline \multirow{2}{*}{$\begin{array}{l}\text { Treatment } \\
\text { chemicals }\end{array}$} & \multirow{2}{*}{$\begin{array}{c}\text { Treatment } \\
\text { dose }\end{array}$} & \multicolumn{5}{|c|}{ Rations (\%) } \\
\hline & & Infected & Sterilized & Survival of embryos & Hatching & Abnormal \\
\hline \multirow{4}{*}{$\begin{array}{c}\text { Methylene } \\
\text { blue } \\
(\mathrm{ppm})\end{array}$} & 40 & $23 \pm 2.1^{\mathrm{a}}$ & $69 \pm 2.4^{\mathrm{a}}$ & $95 \pm 3.8^{\mathrm{a}}$ & $93 \pm 4.6^{\mathrm{a}}$ & $1.0 \pm 0.7^{\mathrm{a}}$ \\
\hline & & & & & & \\
\hline & 80 & $24 \pm 2.2^{\mathrm{b}}$ & $74 \pm 3.4^{\mathrm{b}}$ & $61 \pm 3.9^{\mathrm{b}}$ & $90 \pm 4.1^{\mathrm{b}}$ & $1.4 \pm 0.5^{\mathrm{b}}$ \\
\hline & 160 & $25 \pm 2.9^{c}$ & $94 \pm 2.8^{c}$ & $46 \pm 3.4^{\mathrm{c}}$ & $84 \pm 4.9^{c}$ & $2.0 \pm 0.6^{\mathrm{c}}$ \\
\hline \multirow{3}{*}{$\begin{array}{c}\text { Formalin } \\
(\%)\end{array}$} & 10 & $26 \pm 2.5^{\mathrm{a}}$ & $77 \pm 2.9^{\mathrm{a}}$ & $67 \pm 4.0^{\mathrm{a}}$ & $61 \pm 5.4^{\mathrm{a}}$ & $2.2 \pm 0.9^{\mathrm{a}}$ \\
\hline & 20 & $21 \pm 2.1^{b}$ & $81 \pm 2.8^{\mathrm{b}}$ & $51 \pm 4.1^{\mathrm{b}}$ & $48 \pm 5.1^{b}$ & $3.6 \pm 1.1^{\mathrm{b}}$ \\
\hline & 30 & $28 \pm 2.0^{\mathrm{c}}$ & $98 \pm 3.2^{\mathrm{c}}$ & $42 \pm 4.8^{c}$ & $37 \pm 5.2^{\mathrm{c}}$ & $4.4 \pm 0.8^{c}$ \\
\hline \multirow{3}{*}{$\begin{array}{l}\text { Iodine } \\
(\%)\end{array}$} & 10 & $20 \pm 2.8^{\mathrm{a}}$ & $47 \pm 3.0^{\mathrm{a}}$ & $96 \pm 3.7^{\mathrm{a}}$ & $90 \pm 4.9^{\mathrm{a}}$ & $1.1 \pm 0.7^{\mathrm{a}}$ \\
\hline & 30 & $22 \pm 2.9^{b}$ & $56 \pm 3.4^{\mathrm{b}}$ & $63 \pm 3.4^{\mathrm{b}}$ & $87 \pm 4.5^{b}$ & $1.5 \pm 1.0^{\mathrm{b}}$ \\
\hline & 60 & $23 \pm 2.2^{\mathrm{c}}$ & $90 \pm 3.7^{\mathrm{c}}$ & $47 \pm 3.9^{c}$ & $81 \pm 4.6^{c}$ & $2.3 \pm 1.1^{\mathrm{c}}$ \\
\hline
\end{tabular}

Each value is mean \pm standard error of triplicate experiments $(n=100)$.

The different superscripts are significantly different in each value $(p<0.05)$.

The treatment periods of each chemical were set at $1 \mathrm{hr}$. Infected rates of each group were analyzed at $8 \mathrm{hrs}$ after fertilized. Infected rate showed at ratio of a number of worms regarding a number of a total egg. Sterilized rates of each group were analysis at $1 \mathrm{hr}$ aftertreatment. Sterilized rates of each group showed at ratio of a number of dead worms regarding a number of a total worm. Survival rates of each group were analyzed at $24 \mathrm{hrs}$ after treatment. Hatching rates were analyzed when $90 \%$ of total eggs were hatched. Hatching rates were hatched fish/survival eggs.

$6.4 \%$, and $21.4 \%$ respectively. The $\mathrm{LC}_{50}$ of $\mathrm{MB}$, formalin, and iodine at $96 \mathrm{hrs}$ was $127.3 \mathrm{ppm}, 3.9 \%$, and $13.3 \%$ respectively (Fig. 3). The toxicity sensitivity of formalin was dramatically higher than that of the other chemicals (Fig. 3B). For each graph in Fig. 3A and 3B, equations of $\mathrm{MB}\left(\mathrm{y}=-10.14 \mathrm{x}+1,051, R^{2}=0.708\right)$, formalin $(\mathrm{y}=-0.124 \mathrm{x}+$ $\left.14.51, R^{2}=0.699\right)$, and iodine ( $\mathrm{y}=-0.486 \mathrm{x}+58.16, R^{2}=0.684$ ) were formulated by using these results, and the values of $\mathrm{X}$ and $\mathrm{Y}$ in the equations are the treatment time and $\mathrm{LC}_{50}$ of each chemical respectively.

The mean body length and weight of the adult marine medaka group were $32 \pm 2.4 \mathrm{~mm}(n=300)$ and $313 \pm 52.8 \mathrm{mg}$ $(n=300)$ respectively. The mean body length and weight of the juvenile marine medaka group were $13 \pm 1.6 \mathrm{~mm}(n=300)$ and $26 \pm 5.8 \mathrm{mg}(n=300)$ respectively. The mortality rate of the life-stage groups of marine medaka was recorded in Fig. 4A, 4B, and 4C. Mortality rates in each group were significantly affected by MB concentration and increased drastically as the MB concentration increased $(p<0.05)$. No dead individuals were observed in the control group during the experiment.

Fig. 4A shows the mortality rate in adult group associated with the effect of MB at each concentration. At 120 ppm, the mortality rate was $5 \pm 3.81 \%$, whereas the mortality rate at $150 \mathrm{ppm}$ was $30 \pm 6.34 \%$. Recorded mortality rate at 180,210 , and $240 \mathrm{ppm}$ were $50 \pm 4.40 \%, 70 \pm 5.33 \%$, 

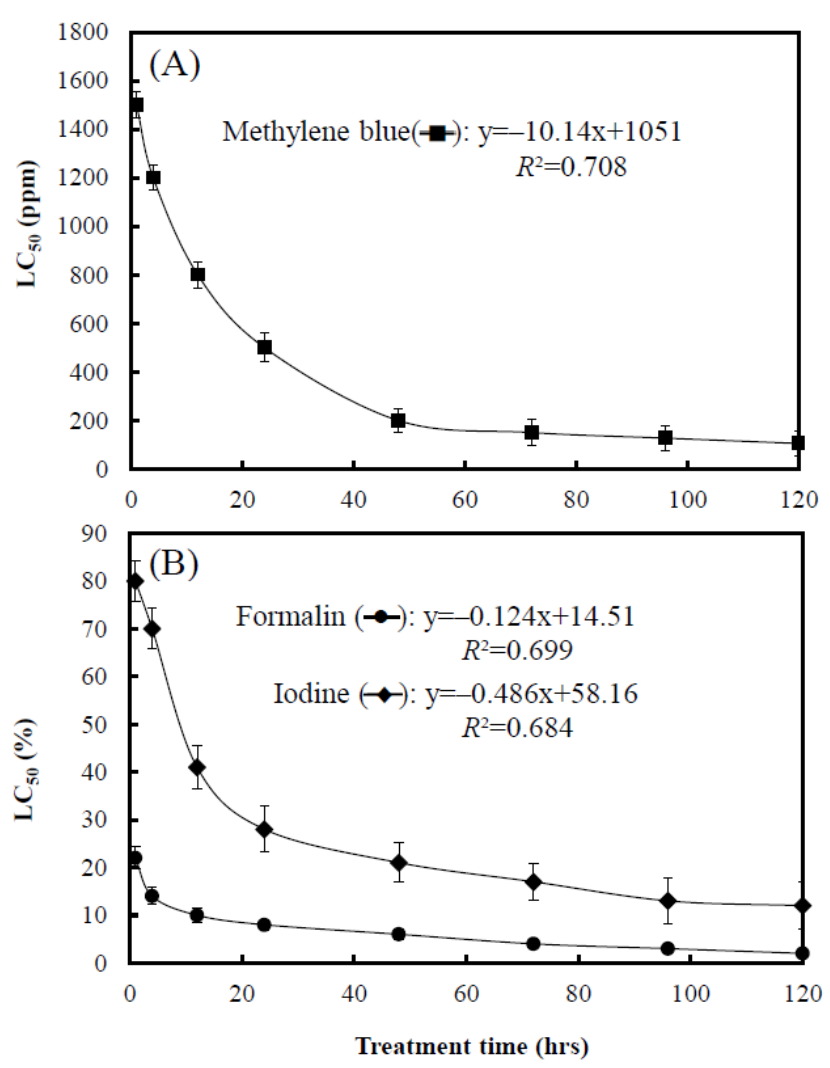

Fig. 3. Lethal concentrations $50\left(\mathrm{LC}_{50}\right)$-treatment time relationship of marine medaka, Oryzias dancena eggs exposed to (A) methylene blue, (B) formalin and iodine for $120 \mathrm{hrs}$. Error bars represent the standard error of triplicate experiments $(p<0.05)$.

and $80 \pm 5.77 \%$ respectively. Fig. 4B shows the mortality rate in juvenile group associated with the effect of $\mathrm{MB}$ at each concentration. At $40 \mathrm{ppm}$, the recorded mortality rate was $15 \pm 5.14 \%$, and the mortality rate at $80 \mathrm{ppm}$ was $40 \pm 4.90 \%$. Mortality rates at 120,160 , and $200 \mathrm{ppm}$ were $60 \pm 4.99 \%, 80 \pm 4.16 \%$, and $90 \pm 5.92 \%$ respectively. Fig. $4 \mathrm{C}$ shows the mortality rate in eggs group associated with the effect of MB at each concentration. At $40 \mathrm{ppm}$, the mortality rate was $5 \pm 3.10 \%$, and the mortality rate at $80 \mathrm{ppm}$ was $30 \pm 5.51 \%$. Mortality rates at 120,160 , and 200 ppm were $45 \pm 6.40 \%, 75 \pm 6.37 \%$, and $85 \pm 3.85 \%$ respectively. For each graph in Fig. 4, equations were formulated by using these results, and the values of $\mathrm{X}$ and $\mathrm{Y}$ in the equations are the MB concentration and mortality respectively. The equation of the adult marine medaka was $y=0.63 x-67.11$,
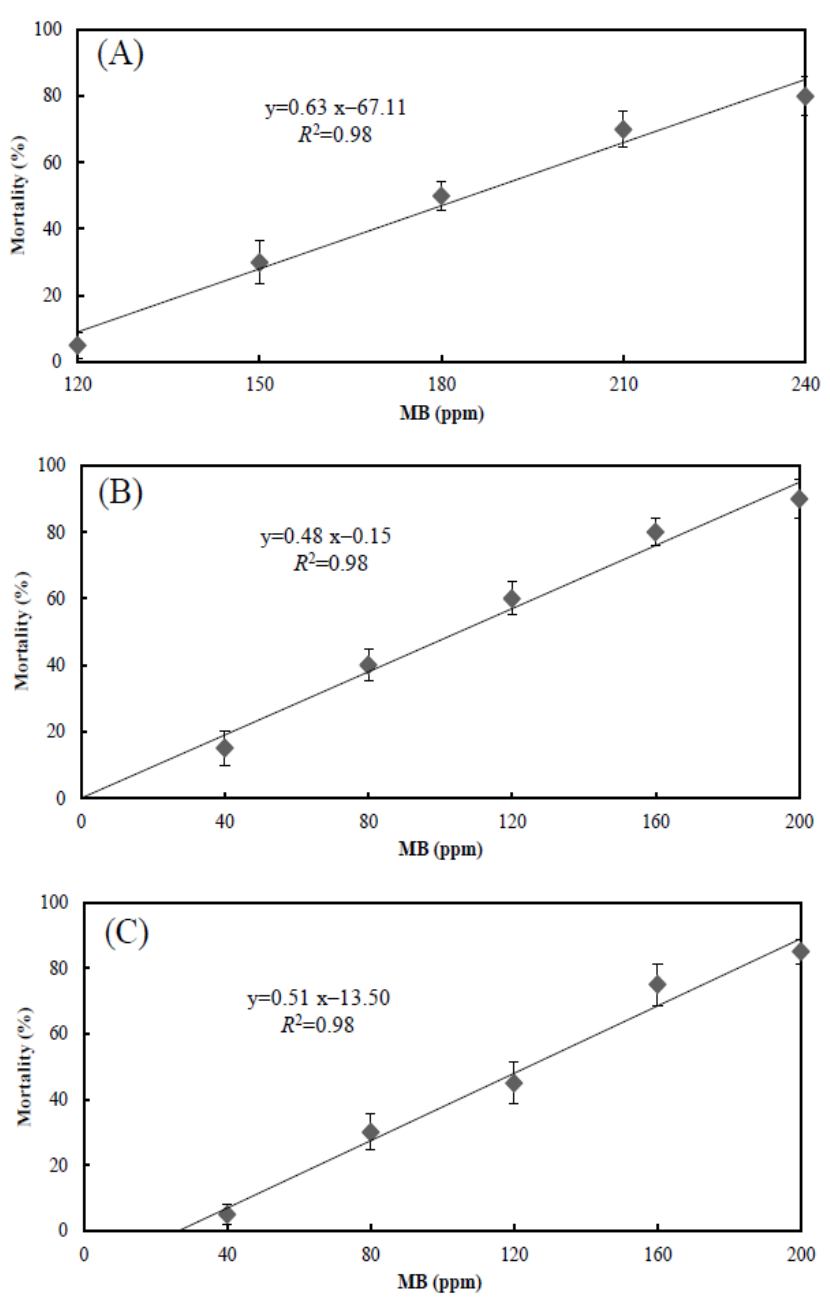

Fig. 4. Dosage-mortality response of marine medaka, Oryzias dancena exposed to methylene blue (MB for 96 hrs. (A) adult stage; (B) juvenile stage; (C) egg stage. Error bars represent the standard error of triplicate experiments $(p<0.05)$.

and the equations of juvenile and egg were $y=0.48 x-0.15$ and $\mathrm{y}=0.51 \mathrm{x}-13.50$ respectively.

The $\mathrm{LC}_{50}$ for each group was measured by the effect of $\mathrm{MB}$ over $96 \mathrm{hrs}$. In the adult group, the $\mathrm{LC}_{50}$ was 185.26 $\mathrm{ppm}$, and the $\mathrm{LC}_{50}$ of the juvenile and egg groups was $103.84 \mathrm{ppm}$ and $127.15 \mathrm{ppm}$ respectively. The 95\% confidence ranges were $171.30-199.86 \mathrm{ppm}$ for the adult group, 81.00-123.44 ppm for the juvenile group, and $108.40-146.48 \mathrm{ppm}$ for the egg group. The toxicity sensitivity of the juvenile group was dramatically higher than that of the other groups. 
Fig. 5 shows gill, liver, and kidney tissues of the control and 100 ppm MB-immersion group. The gills of the marine medaka in the control group had many gill filaments in a comb-shaped row on the gill arch and gill lamellae on each gill filament (Fig. 5A). In contrast, the gill tissue of fish from the MB-immersion group showed swelling of the epithelial cells in the gill filaments and lamellae and fusion

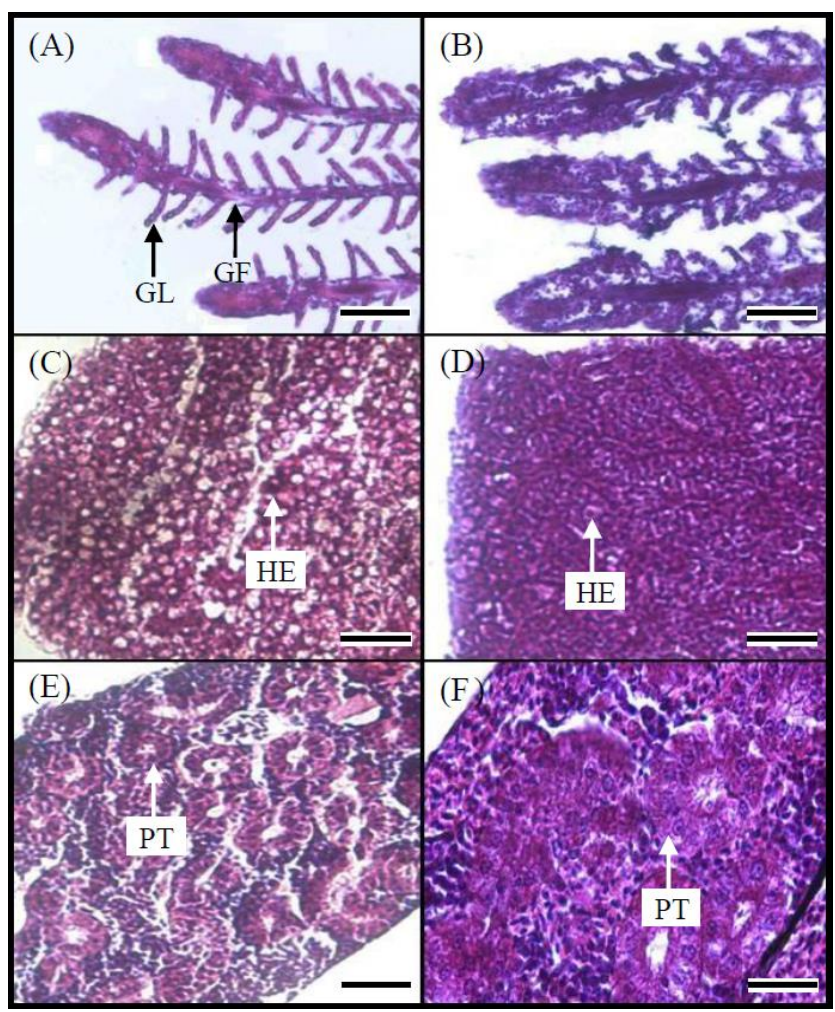

Fig. 5. Histological sections of gill, liver and kidney in marine medaka, Oryzias dancena between in control group and methylene blue (MB) immersion group. (A) Transverse section of gill in control group; (B) Transverse section of gill in MB group; (C) Cross section of liver in control group; (D) Cross section of liver in MB group; (E) Cross section of kidney in control group; (F) Cross section of kidney in MB group. Hematoxylin - Eosin staining. GF: gill filament; GL: gill lamellar; HE: hepatocyte; PT: proximal tubule. Note: It can be observe swelling of gill filaments, lamellae and hepatocytes, expanded cell and nucleus of kidney's proximal tubule in Fig. 5B, 5D, and 5F. Scale bars indicate $30 \mu \mathrm{m}$. and necrosis of the gill lamellae. Particles of MB were caught in gill filaments and lamellae (Fig. 5B). Liver tissue from the marine medaka control group contained round polygonal hepatocytes and the hepatic cord with many hepatocytes could be distinguished, also hepatic veins and capillary vessels were found in many parts of the liver tissue (Fig. 5C). However, swelling of the hepatocytes was frequently observed in the liver tissue of fish from the MBimmersion group, and the hepatocytes were found to be clustered (Fig. 5D). The kidney tissue of marine medaka in the control group was developed along the downward dorsal body wall of the vertebra from the location of the gill cover and were located bilaterally at the center of the spine. The kidney tissue consists of the glomerulus, proximal tubule, etc., and the glomerulus and capillary aggregates were wrapped in Bowman's capsule, a thin membrane. The proximal and distal tubules were covered with cylindrical and cubical epithelium respectively (Fig. 5E). Conversely, for the kidney tissue of fish from the MB-immersion group, the cell and nucleus of proximal tubule had expanded in some individuals or the glomerulus had disappeared, and necrosis and fusion of the renal tubule epithelial cells were observed (Fig. 5F).

Fig. 6A shows the variation of the whole-bodycortisol concentration on the adult marine medaka. During the experimental period (0-48 hrs), the cortisol concentration of the control group was maintained from $1.11 \mu \mathrm{g} / \mathrm{dL}$ to $1.35 \mu \mathrm{g} / \mathrm{dL}$. Also, from 0 to $48 \mathrm{hrs,}$, the cortisol concentration of the MB immersion group was significantly higher than that in the control group. For 48 hrs, the cortisol concentrations of the MB immersion group was $11.8 \mu \mathrm{g} / \mathrm{dL}$ at $1 \mathrm{hr}, 18.1 \mu \mathrm{g} / \mathrm{dL}$ at $6 \mathrm{hrs}, 23.8 \mu \mathrm{g} / \mathrm{dL}$ at $12 \mathrm{hrs}, 21.7$ $\mu \mathrm{g} / \mathrm{dL}$ at $24 \mathrm{hrs}$, and $20.8 \mu \mathrm{g} / \mathrm{dL}$ at $48 \mathrm{hrs}$.

Fig. $6 \mathrm{~B}$ shows the variation of the whole-body glucose concentration on the adult marine medaka. During the experimental period ( $0-48 \mathrm{hrs})$, the glucose concentration of the control group was maintained from $30.4 \mathrm{mg} / \mathrm{dL}$ to $31.2 \mathrm{mg} / \mathrm{dL}$. Also, from 0 to $48 \mathrm{hrs}$, the glucose concen- 

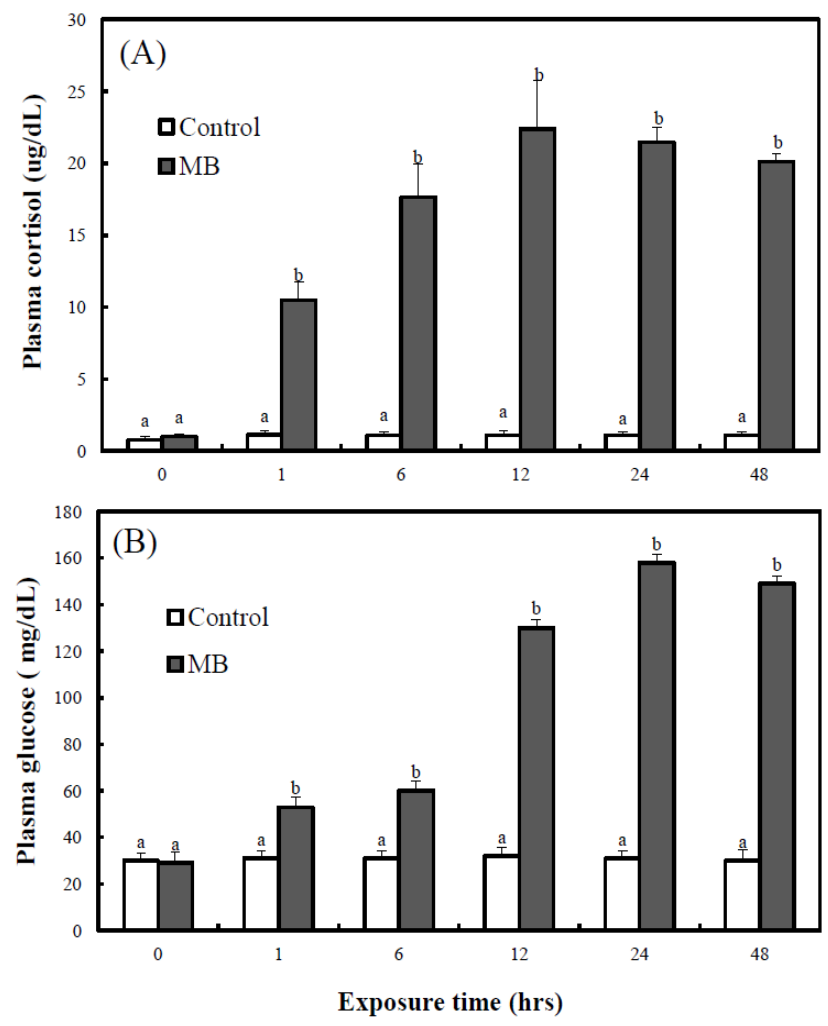

Fig. 6. Variations of the whole body cortisol (A) and glucose (B) concentrations on the adult marine medaka, Oryzias dancena during 48 hrs. Samples of methylene blue (MB) immersion group were exposed at $100 \mathrm{ppm}$ of MB. Values are means $\pm \mathrm{SE}$ $(n=30)$. Actually $n=5$ for each experiment because the means and SE were calculated separately for each group.

tration of the $\mathrm{MB}$ immersion group was significantly higher than that of the control group. For 48 hrs, the glucose concentration of the control group was $29.7 \mathrm{mg} / \mathrm{dL}$ and that of the MB immersion group was $56.2 \mathrm{mg} / \mathrm{dL}$ at $1 \mathrm{hr}$, $60.7 \mathrm{mg} / \mathrm{dL}$ at $6 \mathrm{hrs}, 132.4 \mathrm{mg} / \mathrm{dL}$ at $12 \mathrm{hrs}, 154.7 \mathrm{mg} / \mathrm{dL}$ at $24 \mathrm{hrs}$, and $144.3 \mathrm{mg} / \mathrm{dL}$ at $48 \mathrm{hrs}$. The whole-body cortisol concentration of the MB immersion group was highest at $12 \mathrm{hrs}$, and the whole-body glucose concentration of the MB immersion group was highest at $24 \mathrm{hrs}$.

\section{DISCUSSION}

As Yeom \& Lee (2006) suggested, life stage influenced the toxicity of the agrochemicals, and larvae in a certain stage showed greater sensitivity than did adults. Bentivegna \& Piatkowski (1998) reported that tributyltin had a concentration- and time-dependent effect on the eggs of Japanese medaka, Oryzias latipes. In previous research, higher chemical concentration causes lower survival rate and higher abnormal rate of experimental animals, and the result of our study was similar to that of previous research (Bentivegna \& Piatkowski, 1998; Yeom \& Lee, 2006). In this study, the mortality rate of eggs was higher than that of juvenile marine medaka, $O$. dancena. Eggs have a protective embryonic membrane that provides a buffer against the external environment, contaminants, and toxic chemicals, whereas juveniles do not possess such protection (Blaxter, 1983; Song et al., 2009). The eggs of marine medaka were protected by the embryonic membrane which decreased the permeability of chemicals, resulting the toxicity sensitivity of the eggs was higher than that of the juvenile marine medaka due to the membrane barrier.

As Park et al. (2002) mentioned, the $\mathrm{LC}_{50}$ of formalin in Nile tilapia, Oreochromis niloticus juveniles was 152 ppm, and the toxic effect of formalin was dose dependent. The $\mathrm{LC}_{50}$ and sensitivity to formalin of the marine medaka eggs were similar to those of Nile tilapia juveniles to formalin as reported by Park et al. (2002). For sterilizing all naididae worms, Chaetogaster diastrophus optimum dose range of MB was 180-1,500 ppm, and the treatment period should be less than $1 \mathrm{hr}$, and optimum dose range of formalin and iodine includes $20-30 \mathrm{ppm}$ and $60-80 \mathrm{ppm}$ each. And then the treatment period should be less than 1 hr. Formalin was used as a bactericide in the aquaculture industry (Park et al., 2002), and MB is also widely used as an effective bactericide along with formalin, potassium permanganate, and sodium chloride. Considering our results, sterilization ability of $\mathrm{MB}$ was more effective than formalin and iodine, and MB was more safer than formalin and iodine on the eggs of marine medaka, and the current study verified the sterilization effect of naididae worm on 
the marine medaka eggs.

The $\mathrm{LC}_{50}$ ranking of $\mathrm{MB}$ concentration was presented in the order of adults, eggs, and juveniles. The $\mathrm{LC}_{50}$ of the adult group was higher than that of the juvenile group. This finding was similar to the results of Yeom \& Lee (2006), who performed the study on the acute toxicity of agrochemicals on larvae and juveniles of the oriental weatherfish, Misgurnus anguillicaudatus. As Yeom \& Lee (2006) suggested, life stage influenced the toxicity of the agrochemicals, and larvae in a certain stage showed greater sensitivity than did adults. The $\mathrm{LC}_{50}$ of the marine medaka egg group was higher than that of the marine medaka juvenile group. Bentivegna \& Piatkowski (1998) reported that tributyltin had a concentration- and time-dependent effect on the eggs of Japanese medaka. Eggs have a protective embryonic membrane that provides a buffer against the external environment, contaminants, and toxic chemicals, whereas juveniles do not possess such protection (Song et al., 2009). Thus, eggs were protected by the embryonic membrane against $\mathrm{MB}$, and the $\mathrm{LC}_{50}$ of the egg group was higher than that of the juvenile group.

The tissue lesions observed in the MB-treated marine medaka were similar to the results of the study by Kim et al. (2003) on the histological response of the gill, hepatopancreas, and kidneys of fry of the olive flounder, Paralichthys olivaceus exposed to polychlorinated biphenyls (PCBs). Their observation included the increased gill filament epithelial cells (Kim et al., 2003) and the expansion of mucilage cells, necrosis and fusion of gill lamellae, swelling and vacuolization of hepatocytes, hypertrophy of renal tubules within kidney tissue, and necrosis of renal tubule epithelial cells. Tissue lesions of the gill, liver, and kidney caused by chemical exposure have also been reported; specifically, vacuolization and necrosis of the proximal tubule epithelial cells of goldfish, Carassius auratus exposed to hexachlorobutadiene and the formation of acidophiles with atypical nuclei in the interstitial tissues of a guppy, Poecilia reticulate exposed to bis (tri- $n$-butyltin) oxide
(TBTO) (Wester \& Canton, 1987; Reimschuessel et al., 1989). Fungosity and gill lamellae fusion of various epithelial cells appeared in redbreast sunfish, Lepomis auratus gills containing accumulated PCBs (Teh et al., 1997), and Grinwis et al. (1998) reported that when TBTO was applied to the flounder, Platichthys flesus, the expansion of gill filament and gill lamellae epithelial cells, fusion of gill filaments, and fungosity of gill lamellae epithelial cells began to form, and as the degree of exposure increased, fusion of gill lamellae occurred. Vacuolization was found in the hepatocytes of rainbow trout, Salmo gairdneri exposed to PCBs (Sivarajah et al., 1978), and macrophagocytes were observed in the liver of a redbreast sunfishexposed to PCBs (Teh et al., 1997). In the current study, the fusion and necrosis of gill lamellae, increased gill filament epithelial cells, swelling of hepatocytes, and necrosis and fusion of renal tubule epithelial cells were observed, and it was identified that MB injured the gill, liver, and kidney tissue of marine medaka.

The results in plasma cortisol and plasma glucose concentration of adult marine medaka which were observed in this experiment are indicative of stress reaction. Plasma cortisol and plasma glucose are recognized as useful indicators of stress in fish (Schreck, 1982). According to Barton \& Iwama (1991) and Tort et al. (1996), at the beginning of a chronic stress situation plasma cortisol levels significantly increased and then declined bact to the initial value thereafter. Our results show that plasma cortisol levels increase faster than glucose concentration. This result was similar to the study carried out by Park et al. (2009).

Plasma cortisol and glucose levels in red drum, Sciaenops ocellatus simultaneously exposed to MS-222 and quinaldine anesthetic, were reported to be elevated (Massee et al., 1995). Barton \& Iwama (1991) stated that "Usually, phenomenon that plasma cortisol concentration of fish rises by stress is first order reaction, and phenomenon that plasma glucose concentration rises is second-order reaction 
by hormone rise reaction caused by stress.". This result was reported in the kelp grouper, Epinephelus bruneus (Park et al., 2008). Das et al. (2004) suggested that the greater use of glucose for increased cell metabolism during the early exposure must have overwhelmed the increase in blood glucose, even though glycogenolysis would have increased during this period (Martinez-Alvarez et al., 2002). However, because of dysfunctional cell metabolism the lower use of glucose later in the exposure period (after $48 \mathrm{hrs}$ ) resulted in an increase in blood glucose levels.

The current study verified that the marine medaka can be a useful experimental animal for further toxicological research. This study has provided data on sterilization effect of $\mathrm{MB}$, formalin, and iodine and $\mathrm{LC}_{50}$ of those chemicals regarding treatment times, and future investigations of the marine medaka should focus on the effects of those chemicals on parasite and other aquatic fungus through sterilization. This species will also be used as the experimental animal in research on the acute toxicity of other chemicals. As an experimental animal, in this study, the marine medaka provided data on stage-sensitivity to MB, and future investigations of the marine medaka should focus on the effects of $\mathrm{MB}$ in curing ichthyic diseases through sterilization.

\section{CONFLICT OF INTERESTS}

The authors declare no potential conflict of interest.

\section{ACKNOWLEDGEMENTS}

This study was supported by the National Research Foundation of Korea (NRF) grant funded by the Korea government (MSIP) (No. NRF-2018R1C1B5083024). We thank the staff of the Laboratory of Marine Microbiology at Korea Maritime \& Ocean University (KMOU) for their assistance with sampling and data acquisition. Comments from anonymous reviewers greatly improved the quality of this manuscript. We declare that all experiments in this study comply with the current laws of Korea (the Law Regarding Experimental Animals, No. 9932) and the Ethical Guidelines of KMOU, Korea.

\section{REFERENCES}

Auerbach SS, Bristol DW, Peckham JC, Travlos GS, Hebert CD, Chhabra RS (2010) Toxicity and carcinogenicity studies of methylene blue trihydrate in F344N rats and B6C3F1 mice. Food Chem Toxicol 48:169177.

Barton BA, Iwama GK (1991) Physiological changes in fish from stress in aquaculture with emphasis on the response and effects of corticosteroids. Annu Rev Fish Dis 1:3-26.

Bentivegna CS, Piatkowski T (1998) Effects of tributyltin on medaka (Oryzias latipes) embryos at different stages of development. Aquat Toxicol 44:117-128.

Blaxter JHS (1983) Development: Eggs and larvae. In: Hoar WS, Randall DJ, Donaldson EM, (eds), Fish Physiology, 3rd ed. Reproduction a Growth, Bioluminescence, Pigments, and Poisons, Academic Press, New York, p. 178.

Cho YS, Lee SY, Kim YK, Kim DS, Nam YK (2011) Functional ability of cytoskeletal $\beta$-actin regulator to drive constitutive and ubiquitous expression of a fluorescent reporter throughout the life cycle of transgenic marine medaka Oryzias dancena. Trans Res 20:13331355.

Das PC, Ayyappan S, Jena JK, Das BK (2004) Nitrite toxicity in Cirrhinus mrigala (Ham): Acute toxicity and sub-lethal effect on selected haematological parameters. Aquaculture 235:633-644.

De Lisle PF, Roberts MH (1988) The effects of salinity on cadmium toxicity to the estuarine mysid Mtsidopsis bahia: Role of chemical speciation. Aquat Toxicol 12:357-370. 
Grinwis GCM, Boonstra A, van den Brandhof EJ, Dormans JAMA, Engelsma M, Kuiper RV, van Loveren H, Wester PW, Vaal MA, Vethaak AD, Vos JG (1998) Short-term toxicity of bis (tri- $n$-butyltin) oxide in flounder (Platichthys flesus): Pathology and immune function. Aquat Toxicol 42:15-36.

Handy RD, Sims DW, Giles A, Campbell HA, Musonda MM (1999) Metabolic trade-off between locomotion and detoxification for maintenance of blood chemistry and growth parameters by rainbow trout (Oncorhynchus mykiss) during chronic dietary exposure to copper. Aquat Toxicol 47:23-41.

Im JH, Gil HW, Lee TH, Kong HJ, Ahn CM, Kim BS, Kim DS, Zhang CI, Park IS (2016) Morphometric characteristics and fin dimorphism between male and female on the marine medaka, Oryzias dancena. Dev Reprod 20:331-347.

Inoue K, Takei Y (2003) Asian medaka fishes offer new models for studying mechanisms of seawater adaptation. Comp Biochem Physiol B Biochem Mol Biol 136:635-645.

Kang CK, Tsai SC, Lee TH, Hwang PP (2008) Differential expression of branchial $\mathrm{Na}^{+} / \mathrm{K}^{+}$-ATPase of two medaka species, Oryzias latipes and Oryzias dancena, with different salinity tolerances acclimated to fresh water, brackish water and seawater. Comp Biochem Physiol A Mol Integr Physiol 151:566-575.

Kim JH, Hayward CJ, Heo GJ (2002) Nematode worm infections (Camallanus cotti, Camallanidae) in guppies (Poecilia reticulata) imported to Korea. Aquaculture 205:231-235.

Kim JW, Jee JH, Kang JC, Lee JS, Chin P (2003) Histological response of kidney, gill and hepatopancreas of the juvenile olive flounder, Paralichthys olivaceus after PCBs exposure. J Korean Fish Soc 36:283-289.

Martinez-Alvarez RM, Hidalgo MC, Domezain A, Morales AE, Garcia-Gallego M, Sanz A (2002) Physiological changes of sturgeon Acipenser naccarii caused by in- creasing environmental salinity. J Exp Biol 205:36993706.

Massee KC, Rust MB, Hardy RW, Stickney RR (1995) The effectiveness of tricaine, quinaldine sulfate and metomidate as anesthetics for larval fish. Aquaculture 134:351-359.

Moura JC, Cordeiro N (2003) 3,7-bis(dialkylamino) phenothiazin-5-ium derivatives: Biomedical applications and biological activity. Curr Drug Targets 4:133-141.

Park IS, Choi GC, Noh JK, Kim DS (2002) Acute toxicity of sodium chloride, formaline and potassium permanganate to Nile tilapia fry. Korean J Fish Aquat Sci 15:119-121.

Park IS, Gil HW, Kim DS (2018) Morphometric characteristics of diploid and triploid marine medaka, Oryzias dancena. Dev Reprod 22:183-192.

Park IS, Gil HW, Lee TH, Nam YK, Kim DS (2016) Comparative study of growth and gonad maturation in diploid and triploid marine medaka, Oryzias dancena. Dev Reprod 20:305-314.

Park IS, Gil HW, Lee TH, Nam YK, Lim SG, Kim DS (2017) Effects of clove oil and lidocaine-HCL anesthesia on water parameter during simulated transportation in the marine medaka, Oryzias dancena. Dev Reprod 21:19-33.

Park IS, Park SJ, Gil HW, Nam YK, Kim DS (2011) Anesthetic effects of clove oil and lidocaine- $\mathrm{HCl}$ on marine medak (Oryzias dancena). Lab Animal 40:45-51.

Park MO, Hur WJ, Im SY, Seol DW, Lee JH, Park IS (2008) Anaesthetic efficacy and physiological responses to clove oil-anaestheized kelp grouper, Epinephelus bruneus. Aquacult Res 39:877-884.

Park MO, Im SY, Seol DW, Park IS (2009) Efficacy and physiological responses of rock bream, Oplegnathus fasciatus to anesthetization with clove oil. Aquaculture 287:427-430.

Patel PN (2006) Methylene blue for management of ifosfamide-induced encephalopathy. Ann Pharmacother 
40:299-303.

Raabo E, Terkildsen TC (1960) On the enzymatic determination of blood glucose. Scand J Clin Lab Invest 12:402-407.

Reimchuessel R, Bennett RO, May EB, Lipksy MM (1989) Renal histopathological changes in the goldfish (Carassius auratus) after sublethal exposure to hexachlorobutadiene. Aquat Toxicol 15:169-180.

Roberts TR (1998) Systematic observations on tropical Asian medakas or ricefishes of genus Oryzias, with descriptions of four new species. Ichthyol Res 45:213224.

Schreck CB (1982) Stress and rearing of salmonids. Aquaculture 28:241-249.

Segner H (1987) Response of fed and starved roach, Rutilus rutilus, to sublethal copper contamination. J Fish Biol 30:423-437.

Sivarajah K, Franklin CS, Williams WP (1978) Some histopathological effects of Aroclor 1254 on the liver and gonads of rainbow trout, Salmo gairdneri and carp, Cyprinus carpio. J Fish Biol 13:411-414.

Sola F, Isaia J, Masoni A (1995) Effects of copper on gill structure and transport function in the rainbow trout, Oncorhynchus mykiss. J Appl Toxicol 391-398.

Song HY, Nam YK, Bang IC, Kim DS (2009) Embryogenesis and early ontogenesis of a marine medaka, Oryzias dancena. Korean J Ichthyol 21:227-238.

Teh SJ, Adams SM, Hinton DE (1997) Histopathologic biomarkers in feral freshwater fish populations exposed to different types of contaminant stress. Aquat Toxicol 37:51-70.

Tort L, Gomez E, Montero D, Sunyer JO (1996) Serum haemolytic and agglutinating activity as indicators of fish immunocompetence: Their suitability in stress and dietary studies. Aquac Int 4:31-41.

Wester PW, Canton JH (1987) Histopathological study of Poecilia reticulate (guppy) after long-term exposure to bis(tri- $n$-butyltin) oxide (TBTO) and di- $n$-butyltindichloride (DBTC). Aquat Toxicol 10:143-165.

Yeom DH, Lee SK (2006) Acute toxicity of four agrochemicals on larval and juvenile oriental weatherfish (Misgurnus anguillicaudatus). J Environ Toxicol 21:311316. 